\title{
Pairing your Sox: Identification of Sox11 partner proteins and interaction domains in the developing neural plate
}

\author{
Kaela S. Singleton ${ }^{1}$, Pablo Silva-Rodriguez, and Elena M. Silva ${ }^{1 *}$ \\ Department of Biology, Georgetown University, Washington D.C., 20057; \\ ${ }^{1}$ Interdisciplinary Program in Neuroscience, Georgetown University Medical Center, Washington D.C., \\ 200057 \\ Present address: Regents Hall, $37^{\text {th }}$ and O Street NW, Washington DC 20057 \\ *Corresponding author: Elena M. Silva \\ E-mail: elena.silva@georgetown.edu; Tel.(202)687-0858 \\ Running title: Sox11 partners and interaction domains
}

Keywords: differentiation, neurogenesis, Xenopus, transcription factor, protein-protein interaction 


\section{Abstract}

Sox11, a member of the SoxC family of transcription factors, has distinct functions at different times in neural development. Studies in mouse, frog, chick and zebrafish show that Sox 11 promotes neural fate, neural differentiation, and neuron maturation in the central nervous system. These diverse roles are controlled in part by spatial and temporalspecific protein interactions. However, the partner proteins and Sox11-interaction domains underlying these diverse functions are not well defined. Here, we identify partner proteins and the domains of Xenopus Sox11(xSox11) required for protein interaction and function during neurogenesis. Our data show that Sox 11 co-localizes and interacts with Pou3f2 and Ngn2 in the anterior neural plate and in early neurons, respectively. We also demonstrate that xSox 11 does not interact with Ngn1, a high affinity partner of Sox11 in the mouse cortex, suggesting that Sox 11 has species-specific partner proteins. Additionally, we determined that the N-terminus including the HMG domain of $\mathrm{xSox} 11$ is necessary for interaction with Pou $3 \mathrm{f} 2$ and Ngn2, and established a novel role for the N-terminal 46 amino acids in the establishment of placodal progenitors. This is the first identification of partner proteins for Xenopus Sox11 and of domains required for partner protein interactions and distinct roles in neurogenesis.

\section{Introduction}

The Sry-related HMG box (Sox) family of transcription factors play critical regulatory roles in the development of vertebrates and invertebrates $(1,2)$. All Sox proteins contain a high mobility group (HMG) domain that binds both partner proteins and DNA in order to alter expression of downstream target genes $(3,4)$. Sox transcription factors are grouped into eight subfamilies (A-H), based on sequence homology and functional similarity. The SoxB and SoxC subfamily of proteins play essential roles in orchestrating neurogenesis in the central nervous system (CNS). SoxB1 proteins drive neural progenitor specification and maintenance and SoxC proteins promote differentiation and neuron maturation (5-7). Both SoxB and SoxC proteins have multiple, and sometimes opposing, roles during neurogenesis. For example, the SoxB2 protein, Sox 21 , inhibits neuronal differentiation when overexpressed but is also required at low levels for differentiation (8). Similarly, the SoxB1 protein Sox2, is implicated in embryonic stem cell specification and maintenance, neural progenitor cell competency, and neuron maintenance (9-11). Thus, functional studies in numerous organisms demonstrate that Sox proteins perform unique functions in different neural cell types and at various times during neurogenesis.

Across subfamilies, the HMG domain of Sox proteins is more than $50 \%$ identical, resulting in all Sox proteins binding a similar DNA motif with low affinity (12). Interactions with partner proteins are required to facilitate specific and high affinity binding of Sox proteins to DNA regulatory regions. The most commonly identified partners of Sox proteins in neurogenesis are Pou and E-Box proteins (1315). For example, Sox 2 complexes with Pou5f1, Pou $3 \mathrm{f} 2$ and Ngn2 at various stages in development and drives the expression of different genes in multiple developmental processes $(8,16-18)$. Sox 2 cooperates with Pou5f1 (Oct3/4) to control embryonic stem cell differentiation and later complexes with Pou3f2 (Oct7) to promote neural specification (1921). Sox proteins can also form homo and heterodimers; Sox 2 interacts with Sox 21 to promote ectodermal cell fate in stem cells (17). Additionally, Sox 2 and Sox 21 each bind Ngn2 to promote or inhibit neural differentiation, respectively $(8,22)$. These data indicate that identifying and characterizing partner protein interactions is essential to understanding the regulation of Sox protein function.

Sox proteins use various domains to complex with partner proteins. While many transcriptional partner proteins interact with the Sox HMG domain $(20,23-27)$, some interact with multiple domains or a domain outside of the HMG. Sall4 interacts with the $\mathrm{C}$-terminus, $\mathrm{N}$-terminus and HMG domain of Sox 2 in embryonic stem cells. Others, like HDAC1, interact with only the C-terminus of Sox 2 (28). It has been proposed that protein interactions with domains outside of the HMG serve to stabilize binding of other transcriptional partner proteins $(23,29)$. The reliance on partner proteins for specificity allow for two levels of regulation of Sox protein function: availability of partner proteins within a given cell or tissue type and the relative affinity of partner protein interactions. Through identification of both Sox-partner proteins and interaction domains, we can reveal how Sox proteins 
precisely control gene networks during neurogenesis.

In this study, we identify partner proteins and the interaction and functional domains of the SoxC protein, Sox11, during neurogenesis. Work from our lab and others, has shown that Sox11 is involved in neural induction, and neuron differentiation and maturation (30-33). We recently, characterized Sox 11 expression and function in the Xenopus neural plate and mouse cortex (34). sox 11 expression is found throughout the developing neural plate and cortex, and promotes neuronal maturation in both mouse cortical development and Xenopus neurogenesis. Interestingly, we also found that Sox11 is not functionally interchangeable between these two species like many other Sox transcription factors $(34,35)$. This suggests that Sox11 is essential for neuron formation across species, but the molecular mechanism underlying Sox11 function is not conserved.

To investigate this conundrum and to better understand how Xenopus Sox11 drives neurogenesis, we used an open access single-cell sequencing database to characterize expression of Sox 11 and potential partner proteins Ngn1, Ngn2, and Pou3f2. We found that $\operatorname{sox} 11^{+}$and pou $32^{+}$cells are localized to the anterior neural plate, while $\operatorname{sox} 11^{+}$and $n g n^{+}$ cells are found in early neurons. We also establish that Xenopus Sox11 interacts with Ngn2 and Pou3f2 (also known as Brn2), known partners of Sox11 in mouse cortex (31), but does not interact with Ngn1. We went on to identify the domains of Sox11 needed for both partner protein binding and formation of neural progenitors and mature neurons. Collectively, our data show that the first 46 amino acids in the N-terminus of Sox 11 is required for robust interaction with Ngn2 and Pou3f 2 and formation of neural progenitors in posterior placodes, while the HMG domain of xSox11 is required for both partner protein binding and xSox11 function. Additionally, the C-terminus and transcription activation domain of xSox11 are necessary for formation of neurons in the developing neural plate. These data suggest that Sox11 has species-specific partner proteins to facilitate neuron formation, and that Xenopus Sox11 interacts with different partners to promote numerous functions in various regions of the developing neural plate. These are the first partner proteins identified for
Xenopus Sox11, and the first characterization of Sox 11 protein interaction domains and their contribution to neurogenesis.

\section{RESULTS}

\section{Sox 11 and potential partners are co-expressed in distinct cell types of the neural plate.}

Our previous overexpression studies demonstrated that even though Xenopus Sox11 (xSox11) and mouse SOX11 (mSOX11) promote neural differentiation in their respective species, neither promotes differentiation in the other species. One possibility is that $\mathrm{xSox} 11$ and mSOX11 utilize different partner proteins and therefore different mechanisms to promote differentiation. Therefore, we asked if xSox 11 and mSOX11 interact with the same partner proteins, and focused on three proteins that bind to mSOX11 in the mouse cortex, Ngn1, Ngn2, and Pou3f2 (31).

To determine if the Xenopus orthologues of Ngn1, Ngn2, and Pou3f2 are co-expressed with xSox 11 in the developing neural plate, we screened an open access database, Jamboree, that contains a time series of single cell transcriptome measurements during Xenopus development (36). Our analysis focused on cells in the neural plate marked by sox 2 and sox 3 , the anterior neural plate marked by $n k x 2$ and $f e z f 1$, the posterior neural plate marked by $v g l l 3$, and early neurons marked by $n$-tubulin, myt 1 , and prphl (36). Using this database, we identified cells positive for sox 11 and either ngn or pou $3 f 2$. Due to low sequencing depth, we could not distinguish between $n g n 1, n g n 2$ or $n g n 3$. Thus, for the data presented here, we grouped all $n g n^{+}$cells together.

We identified 2,106 $\operatorname{sox} 11^{+}$cells in the neural plate at stage 12 (late gastrula). At early neurula (stage 13 and 14) there are 924 sox $11^{+}$cells in the anterior neural plate and 1,112 sox $11^{+}$cells in posterior neural plate (Figure 1A, Table S1). In addition, at stage 14, there are 505 sox $11^{+}$cells in early neurons (Figure 1A, Table S1). We examined the number of cells that are $\operatorname{sox} 11^{+}$, sox $11^{+}$and $n g n^{+}$, or $\operatorname{sox} 11^{+}$ and pou $3 \mathrm{f2}^{+}$, and found that the number of cells coexpressing sox 11, ngn or pou $3 f 2$ is high at every developmental stage. Of those, only 12 cells in the 
neural plate and 24 cells in early neurons are positive for all three, $\operatorname{sox} 11^{+}, n g n^{+}$, and pou $3 f^{+}$.

We show that a majority of $n g n^{+}$cells are $\operatorname{sox} 11^{+}$ (Figure 1B, Table S2); 319 of the $341 n g n^{+}$cells, in the neural plate are $\operatorname{sox} 11^{+}$, by stage $13 / 14$ all 29 $n g n^{+}$cells in the anterior neural plate are $\operatorname{sox} 11^{+}$, and 39 of the $44 n g n^{+}$cells in the posterior neural plate are $\operatorname{sox} \mathrm{Il}^{+}$(Figure 1B). The number of $n g n^{+}$ cells peaks in early neurons at stage 14; 413 of the $458 \mathrm{ngn}^{+}$cells are $\operatorname{sox} 11^{+}$. Although there are far fewer pou $3 \mathrm{f}^{+}$cells in late gastrula and early neurula embryos, the majority are also sox $11^{+}$(Figure $1 \mathrm{C}$, Table S3). The highest number of pou $3 \mathrm{f}^{+}$cells are in the anterior neural plate (108 cells) and 98 are sox $11^{+}$. Thus, sox 11 and potential partner proteins are co-expressed in distinct domains of the neural plate (Figure 1D, Table S4). We also confirmed coexpression by performing whole mount in situ hybridization (WISH) analysis of stage 12 (late gastrula) and stage 14 (neurula) Xenopus embryos demonstrating that sox 11 expression overlaps with $n g n 2$ anpou3f2 (Figure S2). In line with our WISH data, previous research shows pou $3 f 2$ expression is not detectable at stage 12 by WISH due to low transcript levels, but is visible at stage 14 in the anterior neural plate (37).

Collectively, these data suggest sox 11 and $n g n$ are co-expressed in the correct place and time to promote neuronal differentiation in late gastrula and early neuron formation in neurula Xenopus embryos (Figure 1D). Furthermore, soxl1 and pou3f2 are also co-expressed in the correct place and time to establish the anterior neural plate in early neurula embryos.

\section{xSox11 partners with Ngn2 and Pou3f2 but not Ngn1.}

To examine the interactions of $\mathrm{xSox} 11$ and potential partner proteins, we generated epitope-tagged expression plasmids: xSox11-FLAG, xPou3f2-HA, xNgn1-HA, and xNgn2-MYC. We performed in vitro translation (IVT) followed by co-immunoprecipitation (co-IP) and western blot analysis (WB) to assay for interactions between xSox11-FLAG and either xPou3f2-HA, xNgn1-HA, or xNgn2-MYC. We show that $x$ Sox11-FLAG interacts with both xPou3f2-HA and xNgn2-MYC (Figure 2A-B), but not with xNgn1-HA (Figure 2C). This was surprising because in mouse cortex, mouse NGN1 (mNGN1) is the preferred partner of mouse SOX11 (mSOX11), based on the abundance of the co-immunoprecipitated proteins (31). To establish if xSox11 interacts with mNGN1, we performed coIP and WB in HEK293 cells. We show that XSox11 does not interact with mNGN1 (Figure 3A), but mSOX11 does (Figure 3B). This suggests that Sox 11 has species-specific partner proteins to drive neural differentiation.

\section{Sox11 N-terminus is necessary for protein-pro- tein interactions.}

To investigate which domains of Sox 11 are necessary for partner protein binding, we generated constructs that express modified xSox11-FLAG protein: $\triangle \mathrm{N} 46-\mathrm{xSox} 11-\mathrm{FLAG}$ that removes 46 amino acids upstream of the HMG domain, $\triangle \mathrm{HMG}-$ xSox11-FLAG that removes the entire 72 amino acid HMG domain, and the $\triangle$ Cterm-xSox11-FLAG that removes 265 amino acids and contains only the $\mathrm{N}$-terminus and HMG of Sox11 (Figure 4A).

To map the protein interaction domains, we performed co-IP of the modified xSox11 proteins and xNgn2 and xPou3f2 using FLAG, HA or MYC antibodies and analyzed samples by WB. Interestingly, the loss of the xSox11 C-terminus does not affect binding of either xPou3f2-HA or xNgn2MYC (Figure 4B-C), and suggests that the C-terminus is not necessary for Sox1linteractions with these two proteins. We next examined how the loss of the N46 xSox11 domain altered interactions with xPou3f2-HA and xNgn2-MYC. Our results show that removal of the N46 domain significantly weakens the interaction with both partners (Figure 4DE). Lastly, removal of the HMG domain prohibits interaction with either partner protein (Figure 4F$\mathrm{G})$. These data reveal that the short 46 amino acid $\mathrm{N}$-terminus of Sox 11 is required for strong partner protein interactions and the HMG domain is necessary for partner protein binding.

\section{Sox 11 C-terminus is required for mature neuron formation.}

Our previous work demonstrated that overexpression of xSox11 increases mature neurons marked by $n$-tubulin (n-tub), and increases neural progenitors marked by sox3 (34). Furthermore, we showed 
that loss of xSox11 reduces mature neurons and increases sox3 (34). To determine the functional significance of xSox11 domains, we analyzed the effect of our mutant $x$ Sox 11 constructs on neurogenesis (Figure 4A). To do this, we injected mRNA from each construct in one cell of a two-cell blastomere embryo, allowed embryos to develop to neurula stage, and assayed by WISH for changes in $n$ $t u b$ and sox3. For domains that are necessary for $\mathrm{xSox} 11$ function, we expect to see no change or a decrease in $n$-tub and/or sox 3 similar to our xSox 11 knockout data, and for domains that are not necessary for xSox11 function, we expect to see an increase in $n$-tub and/or sox 3 in line with our previously published data (34).

Our data reveal that with overexpression of $\Delta$ ctermxsox 11, sox 3 expression remained the same, but $n$ $t u b$ expression was reduced. This result indicates that the $\Delta$ Cterm-xSox11 functions as a dominant negative and like the MO (34) and reduces mature neuron formation. Overexpression of $\Delta n 46-x \operatorname{sox} 11$ leads to ectopic expression of $n-t u b$ in the neural plate and loss of sox 3 expression in placodes (Figure 5). These data show that the $46 \mathrm{~N}$-terminal amino acids are not required for promotion of neural differentiation but is required for placode development. Here the $\Delta$ N46-sox 11 interferes with placode formation and thus functions as a dominant negative.

Next, we overexpressed $\Delta h m g-x \operatorname{sox} 11$. Our data show that there is no difference for either $n-t u b$ or sox3 expression, which we predicted given that Sox transcription factors cannot bind DNA or complex with partners when the HMG is removed (38). We also investigated the role of the 48 amino acid transactivation domain (TAD) located in the $\mathrm{C}$-terminus of Sox $11(39,40)$. We generated a $\Delta$ tad-xsox $11 \mathrm{mu}-$ tant and assayed for its ability to produce protein (Figure S4) and performed the same overexpression experiments analyzing $n-t u b$ and sox3 (Figure 5). We found that without the TAD, xSox 11 shows a slight decrease in $n$-tub and no change in sox 3 expression. This result is in line with previous studies that show the TAD is essential for Sox11 function in vitro (41). Importantly, this is the first time domains of Sox 11 have been characterized in vivo to determine their contribution to neurogenesis. Together, our data show that HMG domain is necessary for $\mathrm{xSox} 11$ function during neuron formation.
Additionally, our data reveal that the N46 domain of $\mathrm{xSox} 11$ is necessary for development of neural progenitors in the placodes, and that the $\mathrm{C}$-terminus of $\mathrm{xSox} 11$, including the TAD, is necessary for mature neuron formation.

\section{Discussion}

Sox transcription factors cooperate with regionspecific partner proteins to regulate down-stream targets and orchestrate neurogenesis. To identify and characterize Sox11-partner protein interactions essential to neurogenesis, we tested whether Sox11 partner proteins are conserved between mouse and Xenopus and identified the domains of Sox11 necessary for protein interaction and function. Previous studies identified Ngn1, Ngn2, and Pou3f2 as binding partners of Sox11 in mouse cortex and in cos9 cells $(31,40)$. We aimed to establish if these interactions also occur in the developing Xenopus neural plate. Our co-expression analysis, using a single cell sequencing database (36), revealed that xSox11 is expressed in the same cells as Ngn1, Ngn2 and Pou $3 \mathrm{f} 2$ at different times in early neural development. sox 11 and $n g n$ are co-expressed predominantly in early neurons, and sox 11 and pou $3 f 2$ cells are abundant in the anterior neural plate (Figure 1). Thus, xSox 11 and these candidate partner proteins are expressed at the same time and place to interact. Through a series of co-IP experiments, we show that xSox11 interacts with Ngn2 and Pou3f2, but not Ngn1 (Figure 2). Importantly, the role of Ngn2 in neurogenesis has been well characterized and complements Sox11 function; Ngn2 governs formation of the first neurons generated in the CNS (42), and Sox 11 drives the formation of early born neurons (43). Thus, our data support the relationship between xSox11 and Ngn2 as essential regulators of early neuron formation.

We also show that $\mathrm{xSox} 11$ interacts with $\mathrm{xPou} 3 \mathrm{f} 2$ (also known as Brn2 or Oct7), however, this relationship is not well defined in Xenopus neural plate development and has various expression patterns and functions across species. Pou3f2 is robustly expressed in stage 14 neurulae but is not detectable in stage 12 gastrulae (Figure SA1) (37). In rat neural precursor cells, Pou3f2 co-localizes with progenitor cell markers and is downregulated upon 
differentiation (44). However, in mouse cortex, Pou3f 2 expression is restricted to upper layer neurons, and loss of both Pou3f2 and family member Pou3f1 results in a decrease in neuronal migration, layer production and neurogenesis (45-47). Thus, Pou3f2 plays critical, but disparate, roles in neurogenesis. Despite this, few studies have investigated the relationship between Sox 11 and Pou3f2. Previous reporter gene studies show that Pou3f2 inhibits mouse Sox 11 transactivation (31). Since neural differentiation is delayed in the anterior neural plate where pou $3 f 2$ and $x$ sox 11 are co-expressed, our data supports the idea that Pou3f2 antagonizes the ability of Sox 11 to promote neurogenesis (Figure 2) (48). Collectively, these data suggest Pou3f2 inhibits Sox 11 function to delay neuronal differentiation.

Our studies reveal that xSox11 does not interact with either Xenopus or mouse Ngn1, suggesting that the partner proteins of Sox 11 vary across species (Figure 3). This was a surprise since mouse Ngn1 is the preferred partner for Sox11 in mouse cortical cells, while Sox4, another SoxC family member, preferentially complexes with Ngn2 (31). One interesting possibility, is that Sox 11 and Sox 4 evolved to interact with different Ngn proteins to allow for the expansion of the mammalian cortex. Sox4 has been partially characterized in Xenopus but only in the eye (49). Thus, future studies on the role of Sox 4 in the neural plate and tube of Xenopus could address these questions. A second possibility is that post translational modification (PTM) or a mediator protein in neural tissue is required for Ngn1 to interact with $x$ Sox 11 . There is precedent for PTMs of mouse Sox 11 in developing mouse retina and hippocampus $(50,51)$. To our knowledge, no studies have investigated PTMs of xSox11 or Ngn1 during neurogenesis. Importantly, our studies were conducted in vitro and did not allow for PTMs of either protein. Mediator proteins have been shown to complex with Ngn1 and other Sox proteins to stabilize reactions and alter function (23). Specifically, when Ngn1 complexes with $\mathrm{CBP} / \mathrm{p} 300$, it facilitates an interaction with Smad1 to inhibit glial cell differentiation and promote neurogenesis (52). Additionally, Sox 2 and Sox6 have been shown to use co-activators and repressors (5355), and Sox 4 has also been shown to require both cytokine interaction and PDZ class proteins to regulate receptor expression (56). These possibilities can be explored in future studies.
In addition to identifying partner proteins of xSox11, we identified the interaction domains. We show that the HMG domain of Sox 11 is necessary for partner protein binding, and the first 46 amino acids of the N-terminus (N46) are essential for strong partner interactions (Figure 4). The HMG domain has been shown to be essential for protein interaction in other Sox proteins. For example, SoxE proteins (Sox8, Sox9, Sox10) require the Cterminal tail of the HMG to complex with partners $(57,58)$. However, in other cases, domains outside of the HMG are required for partner protein interactions. The B-homology domain and C-terminus of Sox 2 is required for partner interactions in stem cells (28) and Sox 18 binds to MEF2C in endothelial cells through its C-terminal domain (59). Thus, similar to other Sox proteins, Sox 11 uses a domain outside of the HMG, to complex with partners, and this likely contributes to its binding specificity (15).

Our previous work demonstrated that overexpression of xSox 11 increases both mature neurons, and neural progenitors (34). Additionally, we showed that knockdown using a morpholino (MO) of $\mathrm{xSox} 11$ results in a decrease in mature neurons, and leads to an increase in neural progenitors, potentially due to progenitors proliferating rather than differentiating. Together, these data establish xSox 11 as a critical protein during early neurogenesis. Our analysis of the functional significance of Sox11 domains revealed embryo phenotypes that support roles for protein domains outside of the HMG in protein interaction. Overexpression of $\Delta$ Cterm-xSox11 mimics the knockdown phenotype: decreased neuron formation as marked by $n$ tub expression (34). This is likely due to $\Delta$ CtermxSox11 functioning as a dominant negative by binding partner proteins in the developing neural plate (Figure 4B-C) and preventing endogenous Sox11 from interacting with these proteins. Since $\Delta$ Cterm-xSox11 lacks the TAD, it is unable to activate target genes. Interestingly, overexpression of $\Delta$ Cterm-xSox11 does not affect neural progenitors in the same way as xSox11 knockdown. The reasons for this are unclear, but since the increase in progenitors is slight in the Sox 11 knockdown embryo, this could simply be due to $\Delta$ Cterm-xSox11 being less effective than the MO. Additionally, we show that excess $\Delta \mathrm{N} 46-\mathrm{x}$ Sox 11 functions similarly to overexpression of xSox 11 in embryos and causes 
an increase in mature neurons. Our binding studies showed that $\Delta \mathrm{N} 46-\mathrm{xS}$ Sox 11 interacts with partner proteins (Ngn2), and since it has an intact C-terminus and TAD, can still activate Sox 11 downstream targets. We also show that overexpression of $\Delta N 46-$ $\mathrm{xSox} 11$ decreases neural progenitors in the placodes (Figure 5). To further investigate this result, we used the single cell sequencing database (36). We identified posterior placodal cells as those expressing pax8, sixl, and sox 9 and found 487 sox $11^{+}$cells out of 618 total cells, supporting the role for Sox11 in placodal development as previously described $(60,61)$. We also confirmed that neither pou $3 f 2$ nor $n g n$ is expressed in posterior placode. Thus, Sox 11 likely works with an unknown placodal partner protein to regulate posterior placodal development. Together, these data show that the C-terminus of Sox 11 is essential for neuron formation, and that further work must be done to elucidate Sox 11 partner proteins in placodal progenitors.

Our overexpression studies demonstrate that $\Delta$ HMG-xSox 11 has no detectable effect on mature neurons or neural progenitors, while overexpression of $\triangle T A D-x S o x 11$ shows a slight decrease in mature neurons and no change in neural progenitors (Figure 5). These results are in line with previous studies that demonstrate the importance of the HMG and TAD domains in other Sox proteins. Numerous studies have shown that the HMG domain is essential to both DNA and partner protein binding $(38,62)$. Additionally, our data underscore the significance of the serine-rich TAD of Sox proteins. Importantly, the TAD of Sox 11 was first shown to be essential in oligodendrocytes and characterized further in $\cos 9$ cells $(39,63)$. Sox 11 is known as the most potent transactivator of the SoxC family, and has even been shown to be more potent than Sox 2 (40).

In conclusions, here we uncover several critical features of Sox11, a protein necessary for neurogenesis. First, $\mathrm{xSox} 11$ is co-expressed with $\mathrm{xPou} 3 \mathrm{f} 2$ and $\mathrm{xNgn} 2$ in the anterior neural plate and early neurons, respectively. Second, Sox11 partner proteins are not conserved across species leading to the enticing possibility that changes in SoxC proteins evolved to enable expansion of the cortex in mammals. Third, the HMG domain and the first 46 amino acids in the N-terminus are necessary for robust partner protein interactions, whereas the $\mathrm{C}$-terminus plays no role in the binding of Pou $3 \mathrm{f} 2$ and Ngn2. Lastly, we show that the C-terminus of Sox 11, and specifically, the TAD is required for promoting neuron formation and progenitors, and the N46 domain of xSox 11 is essential in posterior placodal development. To our knowledge, these are the first partner proteins identified for Xenopus Sox 11 and the first identification of Sox 11 domains essential for protein interaction and neuron formation in the developing neural plate.

\section{Experimental Procedures}

\section{Plasmids}

pCS2+ (used as control in HEK experiments), mNgn2-MYC (gift from Qiang Lu), xPou3f2-HA, xNgn1-HA (HA versions generated by GeneWiz), xNgn2-MYC (gift from Sally Moody), mSox11FLAG (gift from Maria Donoghue) and xSox11FLAG were used. Sox11-FLAG mutants were created by site-directed mutagenesis via polymerase chain reaction with 2XPfu DNA polymerase (Agilent). Primers can be found in Table 1. Each plasmid expressed the correct sized protein as determined by immunoprecipitation (IP) and western blot (WB) analysis (Figure S2-S4).

\section{Identifying Cells using Xenopus time Series Da- tabase}

Single cell transcriptome measurements were taken from Xenopus Jamboree database (kleintools.hms.harvard.edu). Cells in the following categories were analyzed: Neural Plate (Stage 12), Anterior Neural Plate (Stage 13 and 14), Chordal (Posterior) Neural Plate (Stage 13 and 14), and Early Neuron (Stage 13 and 14).

\section{Xenopus animal usage and embryo manipula- tion}

All frog use and care were in accordance with federal and institutional guidelines, particularly Georgetown University's Institutional Animal Care and Use Committee protocols 13-016- 100085. Xenopus laevis embryos were obtained using 
standard methods $(64,65)$ and staged according to the Nieuwkoop \& Faber staging system.

\section{Whole Mount In situ hybridization}

Whole mount in situ hybridization (WISH) was performed as previously described $(66,67)$ with these changes: length of pre-hybridization step was increased to overnight and the RNAse treatment step was eliminated. Digoxygenin labeled probes were generated from plasmids produced by the Silva laboratory.

\section{Frog microinjection}

mRNA used for injections were made in vitro using the mMESSAGE mMACHINE® Transcription Kit (Life Technologies). Embryos were injected with mRNA (1.2ng) and 1:5 Dextran (tracer, ThermoFisher) in one cell of two-cell stage embryos to over-express sox 11 or soxl1 deletion constructs. Embryos were cultured until neurula stage (st. 14) in $1 / 3 \mathrm{MMR}$ at $17^{\circ} \mathrm{C}$ and fixed in Bouins fixative. Embryos were visualized under 488 wavelength fluorescence to identify the injected side following whole mount in situ hybridization experiment.

\section{In vitro translation (IVT) assay}

TNT® SP6 High-Yield Wheat Germ Protein Expression System (Promega) was used to perform in vitro translation assay. Protein products were denatured at $100^{\circ} \mathrm{C}$ for 10 minutes and separated on SDS-PAGE gel. Antibodies for anti-FLAG-HRP (Sigma, 1:2500), anti-HA-HRP (Roche, 1:2500), anti-cMyc-HRP (Abcam, 1:2500), were used to confirm expression.

\section{HEK cells maintenance and transfection}

HEK293 cells were grown in DMEM (Dulbecco's Modified Eagle Medium) supplemented with 10\% fetal bovine serum and $1 \%$ penicillin/streptomycin, and maintained at 37 degrees Celsius with $5 \% \mathrm{CO} 2$ in a humidified environment. Cells were passaged at $\sim 70 \%$ confluency by brief trypsinization at room temperature, followed by serum inactivation and plating in fresh growth media. HEK cells were transfected at 50-60\% confluent in complete growth medium, using X-tremeGENE (Roche), according to manufacturer's instructions. For one well of a 6- well dish, $2 \mu \mathrm{g}$ total DNA was transfected at 1:1 DNA:reagent ratio, where $0.5 \mu \mathrm{g}$ of control plus $1.5 \mu \mathrm{g} /$ well of either Xenopus or mouse Sox11FLAG, and/or Ngn1 expression plasmids was added to total $2 \mu \mathrm{g}$. Transfection cocktail was added directly to the well and left until cell lysis.

\section{Co-immunoprecipitation for IVT Protein}

In vitro translation (IVT) with $500 \mathrm{ng}$ of mRNA was performed using the TnT SP6 High-Yield Protein Expression System (Promega) to synthesize tagged proteins. $66 \%(20 \mu 1)$ of this reaction was subjected to co-IP was while $33 \%(10 \mu 1)$ was saved as input. co-IP for IVT was performed as previously described with the following changes (8). For each co-IP, $10 \mu 1$ reaction mix was mixed with $290 \mu 1$ IP buffer (1\% NP-40, $50 \mathrm{mM}$ Tris-HCl, $\mathrm{pH} 8.0,150$ $\mathrm{mM} \mathrm{NaCl}$ ) containing protease inhibitor cocktail tablet (Roche) and $2 \mu \mathrm{g} / \mathrm{ml}$ of anti-FLAG (Sigma), anti-HA (Cell Signaling), or anti-MYC (Cell Signaling) and incubated for one hour on ice. $25 \mu \mathrm{l}$ Dyna Protein $\mathrm{G}$ magnetic beads (ThermoFisher) were added and the reaction was incubated at $4{ }^{\circ} \mathrm{C}$ overnight on an orbital mixer. The next day, beads were washed three times in cold IP buffer. Buffer was removed and resuspended in $2 \mathrm{X}$ SDS sample buffer with DTT and boiled at $100^{\circ} \mathrm{C}$ for 10 minutes. $12 \mu \mathrm{l}$ of IP sample and $2.5 \mu 1$ of input (also boiled in 2X Laemmli Sample buffer with DTT) were separated via SDS-PAGE on $12 \%$ pre-cast gels (Bio-rad).

\section{Co-immunoprecipitation for HEK293 Lysate}

Transfected HEK cells were lysed in cold immunoprecipitation buffer (1\% NP-40, $50 \mathrm{mM}$ Tris- $\mathrm{HCl}$, $\mathrm{pH} 8.0,150 \mathrm{mM} \mathrm{NaCl}$ ) with protease inhibitors (Roche), and centrifuged for 10 minutes and 3,000 rpm at $4^{\circ} \mathrm{C}$. Supernatant was collected and measured via Bradford Protein Assay (Bio-rad). 200 $\mu \mathrm{g}$ total protein were used in co-IP assays and $5 \mu 1$ of lysate was used as input. For co-immunoprecipitation, Dyna Protein G magnetic beads (ThermoFisher) were washed in IP buffer and incubated with primary antibody (rabbit anti-HA, anti-myc, CST or mouse anti-flag, Sigma) or normal IgG as control (mouse IgG, rabbit IgG, ThermoFisher) at 1:100 dilution for $\geq 1 \mathrm{hr}$, then rinsed in IP buffer. $200 \mu \mathrm{g}$ total protein was incubated with prepared magnetics beads in IP buffer overnight at $4^{\circ} \mathrm{C}$. 
Samples were washed in cold IP buffer before being eluted in 2X Laemmli sample buffer with DTT, boiled, and separated via SDS-PAGE on $12 \%$ precast gels (Bio-rad).

\section{Western Blots}

Western blots were performed using the Bio-Rad Mini TransBlot and TransBlot-Turbo Transfer System, with the Bio-Rad PVDF Transfer Kit. Briefly, samples were loaded onto $12 \%$ Tris-glycine SDS polyacrylamide gels (Bio-Rad), resolved by electrophoresis, transferred to PVDF, and blocked in $5 \%$ non-fat dry milk in TBST (TBS+ $0.1 \%$ Tween20 ) for one hour at room temperature. Following block, blots were incubated with anti-FLAG-HRP
(Sigma, 1:2500), anti-HA-HRP (Roche, 1:2500), anti-myc-HRP (Santa Cruz, 1:2500), anti-beta actin (Sigma, 1:5000) primary antibodies overnight at $4^{\circ} \mathrm{C}$, washed three times with TBST, then incubated with Pierce ECL Plus chemiluminescent substrate (ThermoFisher) and imaged using ImaqeQuant LAS-4000 mini digital imager (GE Healthcare) and visualized for no more than 5 minutes. Input blots were run as control for each experiment, and actin was run as a loading control for HEK experiments.

\section{Data Availability}

All data are contained within the article. 


\section{Acknowledgments}

We thank members of the Silva lab for scientific editing of the manuscript.

\section{Funding and additional information}

This work was supported in part by NIH grant NS078741. KSS is supported by the Center of Neural Injury and Plasticity (5T32NS041218) and NINDS Pre-doctoral to postdoctoral advancement in neuroscience grant (F99NS108539). PSR received support from the Fulbright Foundation.

\section{Conflict of interest}

The authors declare they have no conflicts of interest with the contents of this article.

\section{References}

1. Sarkar, A., and Hochedlinger, K. (2013) The sox family of transcription factors: versatile regulators of stem and progenitor cell fate. Cell Stem Cell. 12, 15-30

2. Phochanukul, N., and Russell, S. (2010) No backbone but lots of Sox: Invertebrate Sox genes. Int $J$ Biochem Cell Biol. 42, 453-464

3. Kondoh, H., and Kamachi, Y. (2010) SOX-partner code for cell specification: Regulatory target selection and underlying molecular mechanisms. Int J Biochem Cell Biol. 42, 391-399

4. $\quad$ Kiefer, J. C. (2007) Back to basics: Sox genes. Dev Dyn. 236, 2356-2366

5. Bergsland, M., Ramsköld, D., Zaouter, C., Klum, S., Sandberg, R., Muhr, J., Ramskold, D., Zaouter, C., Klum, S., Sandberg, R., and Muhr, J. (2011) Sequentially acting Sox transcription factors in neural lineage development. Genes Dev. 25, 2453-2464

6. Reiprich, S., and Wegner, M. (2014) From CNS stem cells to neurons and glia: Sox for everyone. Cell Tissue Res. 10.1007/s00441-014-1909-6

7. Hyodo-Miura, J., Urushiyama, S., Nagai, S., Nishita, M., Ueno, N., and Shibuya, H. (2002) Involvement of NLK and Sox11 in neural induction in Xenopus development. Genes Cells. 7, 487-496

8. Whittington, N., Cunningham, D., Le, T. K., De Maria, D., and Silva, E. M. (2015) Sox21 regulates the progression of neuronal differentiation in a dose-dependent manner. Dev. Biol. 397, 237-247

9. Kopp, J. L., Ormsbee, B. D., Desler, M., and Rizzino, A. (2008) Small Increases in the Level of Sox2 Trigger the Differentiation of Mouse Embryonic Stem Cells. Stem Cells. 26, 903-911

10. Taranova, O. V., Magness, S. T., Fagan, B. M., Wu, Y., Surzenko, N., Hutton, S. R., and Pevny, L. H. (2006) SOX2 is a dose-dependent regulator of retinal neural progenitor competence. Genes Dev. 20, 1187-1202

11. Ferri, A. L., Cavallaro, M., Braida, D., Di Cristofano, A., Canta, A., Vezzani, A., Ottolenghi, S., Pandolfi, P. P., Sala, M., DeBiasi, S., and Nicolis, S. K. (2004) Sox2 deficiency causes neurodegeneration and impaired neurogenesis in the adult mouse brain. Development. 131, 38053819

12. Wegner, M. (1999) From head to toes: the multiple facets of Sox proteins. Nucleic Acids Res. 27, $1409-1420$

13. Kuhlbrodt, K., Herbarth, B., Sock, E., Enderich, J., Hermans-Borgmeyer, I., and Wegner, M. (1998) Cooperative function of POU proteins and SOX proteins in glial cells. J. Biol. Chem. 273, $16050-16057$

14. Kamachi, Y., Uchikawa, M., and Kondoh, H. (2000) Pairing SOX off: with partners in the regulation of embryonic development. Trends Genet. 16, 182-187

15. Wilson, M., and Koopman, P. (2002) Matching SOX: partner proteins and co-factors of the SOX family of transcriptional regulators. Curr Opin Genet Dev. 12, 441-446

16. Chew, J.-L., Loh, Y.-H., Zhang, W., Chen, X., Tam, W.-L., Yeap, L.-S., Li, P., Ang, Y.-S., Lim, B., Robson, P., and Ng, H.-H. (2005) Reciprocal Transcriptional Regulation of Pou5f1 and Sox2 via the Oct4/Sox2 Complex in Embryonic Stem Cells. Mol. Cell. Biol. 25, 6031-6046 
17. Mallanna, S. K., Ormsbee, B. D., Iacovino, M., Gilmore, J. M., Cox, J. L., Kyba, M., Washburn, M. P., and Rizzino, A. (2010) Proteomic analysis of Sox2-associated proteins during early stages of mouse embryonic stem cell differentiation identifies Sox 21 as a novel regulator of stem cell fate. Stem Cells. 28, 1715-1727

18. Wegner, M., and Stolt, C. C. (2005) From stem cells to neurons and glia: a Soxist's view of neural development. Trends Neurosci. 28, 583-588

19. Chew, L. J., and Gallo, V. (2009) The Yin and Yang of Sox proteins: Activation and repression in development and disease. J Neurosci Res. 87, 3277-3287

20. Yuan, H., Corbi, N., Basilico, C., and Dailey, L. (1995) Developmental-specific activity of the FGF-4 enhancer requires the synergistic action of Sox2 and Oct-3. Genes Dev. 9, 2635-2645

21. Tanaka, S., Kamachi, Y., Tanouchi, A., Hamada, H., Jing, N., and Kondoh, H. (2004) Interplay of SOX and POU factors in regulation of the Nestin gene in neural primordial cells. Mol Cell Biol. 24, 8834-8846

22. Zhao, P., Zhu, T., Lu, X., Zhu, J., and Li, L. (2015) Neurogenin 2 enhances the generation of patient-specific induced neuronal cells. Brain Res. 1615, 51-60

23. Wilson, M., and Koopman, P. (2002) Matching SOX: partner proteins and co-factors of the SOX family of transcriptional regulators. Curr Opin Genet Dev. 12, 441-446

24. Wissmüller, S., Kosian, T., Wolf, M., Finzsch, M., Wegner, M., Wißmü, S., Kosian, T., Wolf, M., Finzsch, M., and Wegner, M. (2006) The high-mobility-group domain of Sox proteins interacts with DNA-binding domains of many transcription factors. Nucleic Acids Res. 34, 1735-44

25. Yuan, X., Lu, M. L., Li, T., and Balk, S. P. (2001) SRY Interacts with and Negatively Regulates Androgen Receptor Transcriptional Activity. J. Biol. Chem. 10.1074/jbc.M108404200

26. De Santa Barbara, P., Bonneaud, N., Boizet, B., Desclozeaux, M., Moniot, B., Sudbeck, P., Scherer, G., Poulat, F., and Berta, P. (1998) Direct Interaction of SRY-Related Protein SOX9 and Steroidogenic Factor 1 Regulates Transcription of the Human Anti-Müllerian Hormone Gene. Mol. Cell. Biol. 10.1128/mcb.18.11.6653

27. Botquin, V., Hess, H., Fuhrmann, G., Anastassiadis, C., Gross, M. K., Vriend, G., and Schöler, H. R. (1998) New POU dimer configuration mediates antagonistic control of an osteopontin preimplantation enhancer by Oct-4 and Sox-2. Genes Dev. 10.1101/gad.12.13.2073

28. Cox, J. L., Mallanna, S. K., Luo, X., and Rizzino, A. (2010) Sox2 uses multiple domains to associate with proteins present in Sox2-protein complexes. PLoS One. 5, e15486

29. Bowles, J., Schepers, G., and Koopman, P. (2000) Phylogeny of the SOX family of developmental transcription factors based on sequence and structural indicators. Dev. Biol. 227, 239-255

30. Uy, B. R., Simoes-Costa, M., Koo, D. E. S., Sauka-Spengler, T., and Bronner, M. E. (2015) Evolutionarily conserved role for SoxC genes in neural crest specification and neuronal differentiation. Dev. Biol. 397, 282-292

31. Chen, C., Lee, G. A., Pourmorady, A., Sock, E., and Donoghue, M. J. (2015) Orchestration of Neuronal Differentiation and Progenitor Pool Expansion in the Developing Cortex by SoxC Genes. J. Neurosci. 35, 10629-10642

32. Bergsland, M., Werme, M., Malewicz, M., Perlmann, T., and Muhr, J. (2006) The establishment of neuronal properties is controlled by Sox 4 and Sox11. Genes Dev. 20, 3475-3486

33. Jankowski, M. P., Cornuet, P. K., McIlwrath, S., Koerber, H. R., and Albers, K. M. (2006) SRYbox containing gene 11 (Sox11) transcription factor is required for neuron survival and neurite growth. Neuroscience. 143, 501-514

34. Chen, C., Jin, J., Lee, G. A., Silva, E., and Donoghue, M. (2016) Cross-species functional analyses reveal shared and separate roles for Sox11 in frog primary neurogenesis and mouse cortical neuronal differentiation. Biol. Open

35. Carl, S. H., and Russell, S. (2015) Common binding by redundant group B Sox proteins is evolutionarily conserved in Drosophila. BMC Genomics. 16, 292

36. Briggs, J. A., Weinreb, C., Wagner, D. E., Megason, S., Peshkin, L., Kirschner, M. W., and Klein, A. M. (2018) The dynamics of gene expression in vertebrate embryogenesis at single-cell 
resolution. Science (80-. ). 10.1126/science.aar5780

37. Cosse-Etchepare, C., Gervi, I., Buisson, I., Formery, L., Schubert, M., Riou, J. F., Umbhauer, M., and Le Bouffant, R. (2018) Pou3f transcription factor expression during embryonic development highlights distinct pou3f3 and pou3f4 localization in the Xenopus laevis kidney. Int. J. Dev. Biol. 62, 325-334

38. Weiss, M. a (2001) Floppy SOX: mutual induced fit in hmg (high-mobility group) box-DNA recognition. Mol. Endocrinol. 15, 353-62

39. Dy, P., Penzo-Méndez, A., Wang, H., Pedraza, C. E., Macklin, W. B., Lefebvre, V., PenzoMendez, A., Wang, H., Pedraza, C. E., Macklin, W. B., and Lefebvre, V. (2008) The three SoxC proteins--Sox4, Sox 11 and Sox12--exhibit overlapping expression patterns and molecular properties. Nucleic Acids Res. 36, 3101-3117

40. Wiebe, M. S., Nowling, T. K., and Rizzino, A. (2003) Identification of novel domains within Sox2 and Sox-11 involved in autoinhibition of DNA binding and partnership specificity. J. Biol. Chem. 278, 17901-17911

41. Dy, P., Penzo-Méndez, A., Wang, H., Pedraza, C. E., Macklin, W. B., and Lefebvre, V. (2008) The three SoxC proteins - Sox4, Sox11 and Sox12 - Exhibit overlapping expression patterns and molecular properties. Nucleic Acids Res. 10.1093/nar/gkn162

42. Ma, Q., Kintner, C., and Anderson, D. J. (1996) Identification of neurogenin, a vertebrate neuronal determination gene. Cell. 87, 43-52

43. Kavyanifar, A., Turan, S., and Lie, D. C. (2018) SoxC transcription factors: multifunctional regulators of neurodevelopment. Cell Tissue Res. 10.1007/s00441-017-2708-7

44. Kim, D. K., Han, S. B., Hong, S. T., Choi, Y. J., Sun, W., Geum, D., and Kim, H. (2008) Expression of Sox 11 and Brn transcription factors during development and following transient forebrain ischemia in the rat. Neurosci Lett. 433, 259-264

45. Cook, A. L., and Sturm, R. A. (2008) POU domain transcription factors: BRN2 as a regulator of melanocytic growth and tumourigenesis. Pigment Cell Melanoma Res. 21, 611-626

46. Dominguez, M. H., Ayoub, A. E., and Rakic, P. (2013) POU-III Transcription Factors (Brn1, Brn2, and Oct6) Influence Neurogenesis, Molecular Identity, and Migratory Destination of UpperLayer Cells of the Cerebral Cortex. Cereb. Cortex. 23, 2632-2643

47. Sugitani, Y., Nakai, S., Minowa, O., Nishi, M., Jishage, K. I., Kawano, H., Mori, K., Ogawa, M., and Noda, T. (2002) Brn-1 and Brn-2 share crucial roles in the production and positioning of mouse neocortical neurons. Genes Dev. 16, 1760-1765

48. Papalopulu, N., and Kintner, C. (1996) A posteriorising factor, retinoic acid, reveals that anteroposterior patterning controls the timing of neuronal differentiation in Xenopus neuroectoderm. Development

49. Cizelsky, W., Hempel, A., Metzig, M., Tao, S., Hollemann, T., Kuhl, M., and Kuhl, S. J. (2013) sox 4 and sox 11 function during Xenopus laevis eye development. PLoS One. 8, e69372

50. Balta, E. A., Wittmann, M. T., Jung, M., Sock, E., Haeberle, B. M., Heim, B., von Zweydorf, F., Heppt, J., von Wittgenstein, J., Gloeckner, C. J., and Lie, D. C. (2018) Phosphorylation modulates the subcellular localization of SOX11. Front. Mol. Neurosci. 10.3389/fnmol.2018.00211

51. Chang, K.-C. C., Hertz, J., Zhang, X., Jin, X.-L. L., Shaw, P., Derosa, B. A., Li, J. Y., Venugopalan, P., Valenzuela, D. A., Patel, R. D., Russano, K. R., Alshamekh, S. A., Sun, C., Tenerelli, K., Li, C., Velmeshev, D., Cheng, Y., Boyce, T. M., Dreyfuss, A., Uddin, M. S., Muller, K. J., Dykxhoorn, D. M., and Goldberg, J. L. (2017) Novel Regulatory Mechanisms for the SoxC Transcriptional Network Required for Visual Pathway Development. J. Neurosci. 37, 4967-4981

52. Sun, Y., Nadal-Vicens, M., Misono, S., Lin, M. Z., Zubiaga, A., Hua, X., Fan, G., and Greenberg, M. E. (2001) Neurogenin promotes neurogenesis and inhibits glial differentiation by independent mechanisms. Cell. 104, 365-376

53. Engelen, E., Akinci, U., Bryne, J. C., Hou, J., Gontan, C., Moen, M., Szumska, D., Kockx, C., Van Ijcken, W., Dekkers, D. H. W., Demmers, J., Rijkers, E. J., Bhattacharya, S., Philipsen, S., Pevny, L. H., Grosveld, F. G., Rottier, R. J., Lenhard, B., and Poot, R. A. (2011) Sox2 cooperates with 
Chd7 to regulate genes that are mutated in human syndromes. Nat. Genet. 43, 607-611

54. Murakami, A., Ishida, S., Thurlow, J., Revest, J.-M., and Dickson, C. (2001) SOX6 binds CtBP2 to repress transcription from the Fgf-3 promoter

55. Nowling, T. K., Johnson, L. R., Wiebe, M. S., and Rizzino, A. (2000) Identification of the Transactivation Domain of the Transcription Factor Sox-2 and an Associated Co-activator*, [online] http://www.jbc.org/ (Accessed March 10, 2020)

56. Geijsen, N., Uings, I. J., Pals, C., Armstrong, J., McKinnon, M., Raaijmakers, J. A. M., Lammers, J. W. J., Koenderman, L., and Coffer, P. J. (2001) Cytokine-specific transcriptional regulation through an IL-5R $\alpha$ interacting protein. Science (80-. ). 293, 1136-1138

57. Wißmü, S., Kosian, T., Wolf, M., Finzsch, M., and Wegner, M. The high-mobility-group domain of Sox proteins interacts with DNA-binding domains of many transcription factors. 10.1093/nar/gkl105

58. Marshall, O. J., and Harley, V. R. (2001) Identification of an interaction between SOX9 and HSP70. FEBS Lett. 496, 75-80

59. Hosking, B. M., Wang, S. C. M., Chen, S. L., Penning, S., Koopman, P., and Muscat, G. E. O. (2001) SOX18 directly interacts with MEF2C in endothelial cells. Biochem. Biophys. Res. Commun. 287, 493-500

60. Moody, S. A., and Lamantia, A.-S. (2015) Transcriptional regulation of cranial sensory placode development HHS Public Access. Curr Top Dev Biol. 111, 301-350

61. Saint-Jeannet, J. P., and Moody, S. A. (2014) Establishing the pre-placodal region and breaking it into placodes with distinct identities. Dev. Biol. 389, 13-27

62. Bernard, P., and Harley, V. R. (2010) Acquisition of SOX transcription factor specificity through protein-protein interaction, modulation of $\mathrm{Wnt}$ signalling and post-translational modification. Int. J. Biochem. Cell Biol. 42, 400-410

63. Kuhlbrodt, K., Herbarth, B., Sock, E., Enderich, J., Hermans-Borgmeyer, I., and Wegner, M. (1998) Cooperative function of POU proteins and SOX proteins in glial cells. J. Biol. Chem. $10.1074 / \mathrm{jbc} .273 .26 .16050$

64. Sive, H. L., Grainger, R. M., and Harland, R. M. (2007) Baskets for In Situ Hybridization and Immunohistochemistry. Cold Spring Harb. Protoc. 2007, pdb.prot4777-pdb.prot4777

65. Sive, H. L., Grainger, R. M., and Harland, R. M. (2000) Early development of Xenopus laevis : a laboratory manual, Cold Spring Harbor Laboratory Press

66. Harland, R. M. (1991) In situ hybridization: an improved whole-mount method for Xenopus embryos. Methods Cell Biol. 36, 685-695

67. Hemmati-Brivanlou, A., Frank, D., Bolce, M. E., Brown, B. D., Sive, H. L., and Harland, R. M. (1990) Localization of specific mRNAs in Xenopus embryos by whole-mount in situ hybridization. Development. 110, 325-30 
bioRxiv preprint doi: https://doi.org/10.1101/2020.04.23.057919; this version posted April 24, 2020. The copyright holder for this preprint (which

was not certified by peer review) is the author/funder, who has granted bioRxiv a license to display the preprint in perpetuity. It is made available under aCC-BY-NC-ND 4.0 International license.

Table 1. Primers for $\mathrm{xSox} 11$ deletion constructs

\begin{tabular}{|l|l|l|}
\hline Construct & Forward & Reverse \\
\hline $\begin{array}{l}\Delta \text { N46-xSox11- } \\
\text { FLAG }\end{array}$ & 5'TCCCATCGATGCGCCACCGGG 3' & 5' CCCGGTGGCGCATCGATGGGA 3' \\
\hline $\begin{array}{l}\Delta \text { Cterm-xSox11- } \\
\text { FLAG }\end{array}$ & 5' ACGTCTCCCTCTGACTAGAACTATA 3' & 5' TATAGTTCTAGTCAGAGGGAGACGT 3' \\
\hline $\begin{array}{l}\Delta \text { HMG-xSox11- } \\
\text { FLAG }\end{array}$ & 5' GGCCACCGGGCCCAGGAAAAAG 3' & 5' CTTTTTCCTGGGCCCGGTGGCC 3' \\
\hline $\begin{array}{l}\Delta \text { TAD-xSox11- } \\
\text { FLAG }\end{array}$ & 5' ACGTCTCCCTCGACTACAAAGAC 3' & 5' GTCTTTGTAGTCGAGGGAGACGT 3' \\
\hline
\end{tabular}




\section{Figures}

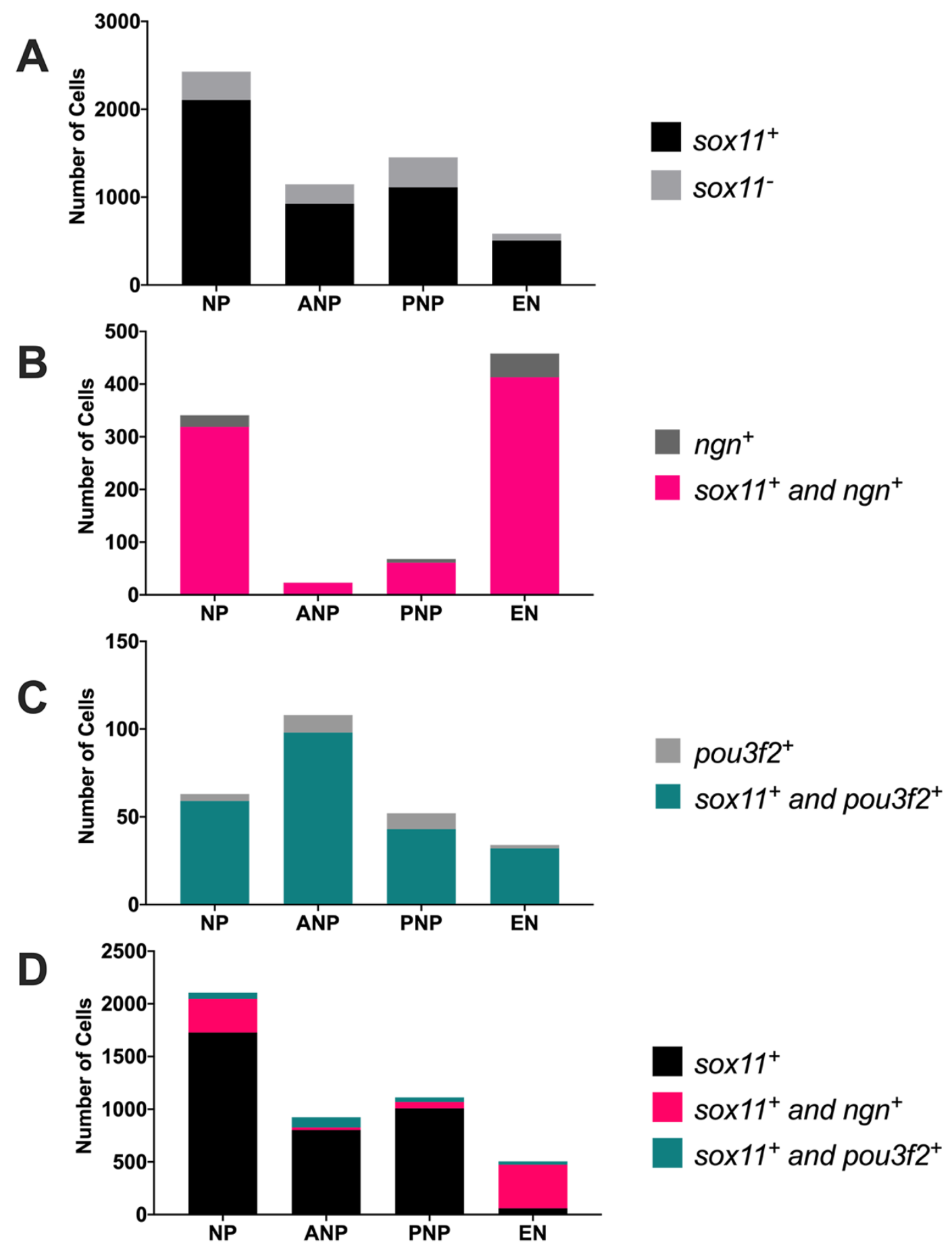

Figure 1 Sox11 and potential partners are co-expressed in distinct cell types of the neural plate. A Total number of cells that are sox $11^{+}$(black) or $\operatorname{sox} 11^{-}$(gray) within the neural plate (NP) at stage 12, the anterior neural plate (ANP), posterior neural plate (PNP) and early neurons (EN). B-C Number of cells across developmental stages that are $n g n+$ (dark gray), $n g n+$ and sox $11+$ (magenta) or pou $3 f 2+$ (light gray) and pou $3 f 2+$ and soxl1+ (teal). D Number of $\operatorname{soxl} 1^{+}$(black) sox $11^{+}$and $n g n^{+}$(magenta), soxl $1^{+}$and pou $3 f 2^{+}$(teal) cells grouped together. 

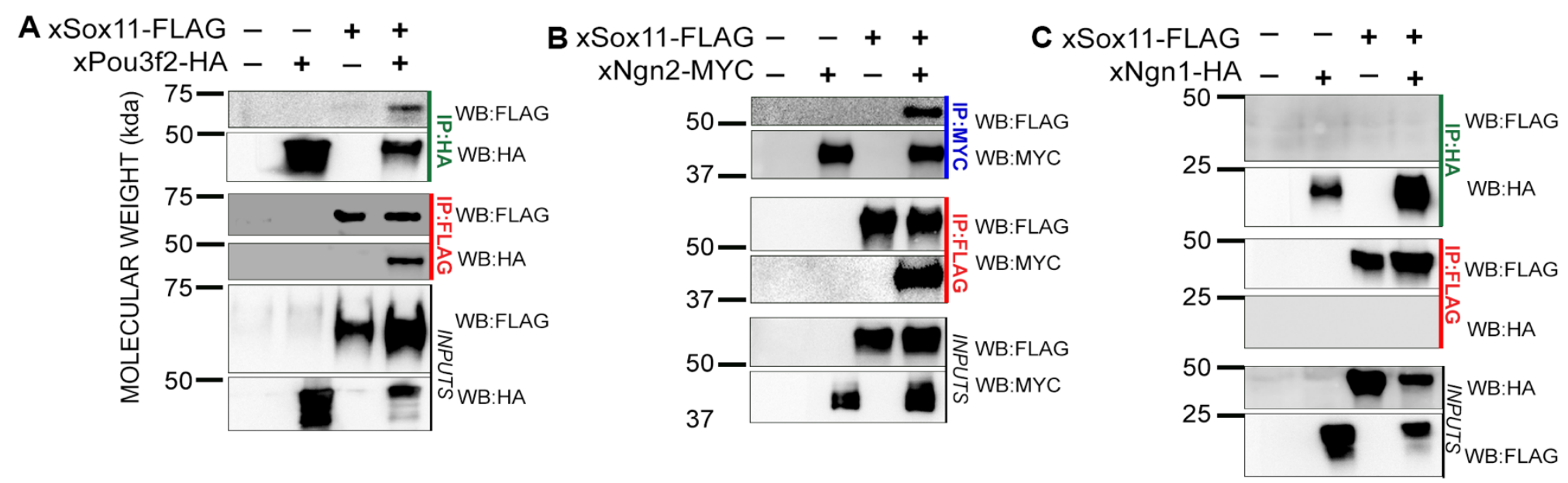

Figure 2 Xenopus Sox11 interacts with xPou3f 2 and xNgn2, but not xNgn1

A-D Immunoprecipitation (IP) of xSox11-FLAG and xPou3f2-HA (A), xNgn2-MYC (B) or xNgn1-HA (C) from in vitro translated proteins. Proteins were immunoprecipitated using either FLAG (red), HA (green) or MYC (blue) antibodies. Samples were analyzed by western blot (WB) indicated on the right with FLAG-HRP, MYC-HRP or HA-HRP. Inputs were run as control. 

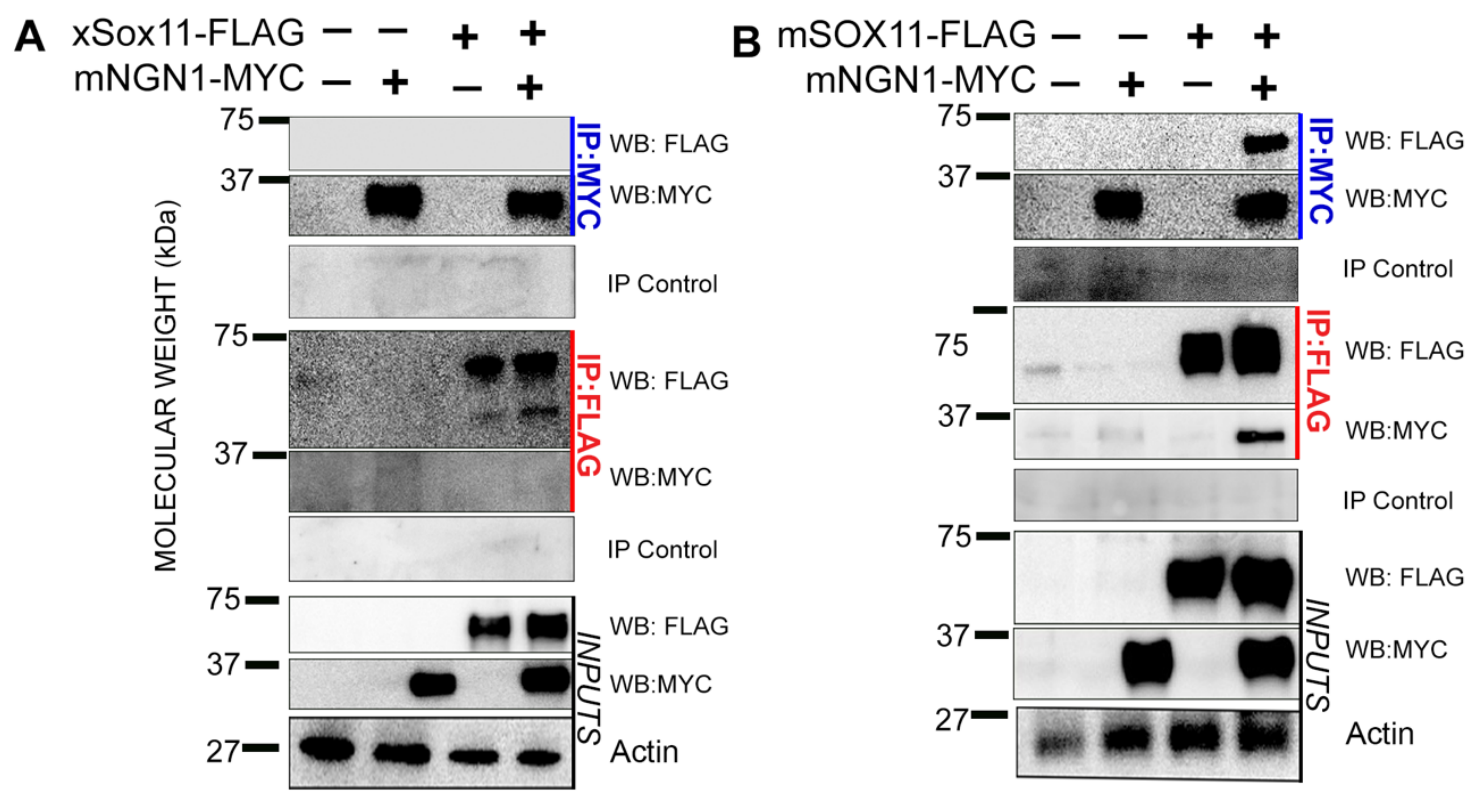

Figure 3 mSOX11 interacts with mNGN1, but xSox11 does not.

A-B Immunoprecipitation (IP) of xSox11-FLAG (A), mouse SOX11-FLAG (mSOX11-FLAG, B), with mouse NGN1-MYC (mNGN1-MYC) using either FLAG (red) or MYC (blue) antibodies in HEK293 cells. Samples were analyzed using western blot (WB) with either anti-FLAG-HRP or anti-MYC-HRP. Inputs, actin, and IgG (IP Control) were run as control. 
bioRxiv preprint doi: https://doi.org/10.1101/2020.04.23.057919; this version posted April 24, 2020. The copyright holder for this preprint (which was not certified by peer review) is the author/funder, who has granted bioRxiv a license to display the preprint in perpetuity. It is made available under aCC-BY-NC-ND 4.0 International license.

A

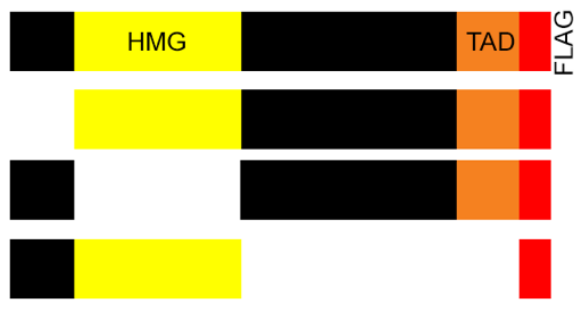

xSox11-FLAG

$\Delta$ N46-xSox11-FLAG

$\triangle$ HMG-xSox11-FLAG

$\Delta$ CTerm-xSox11-FLAG

\section{B}

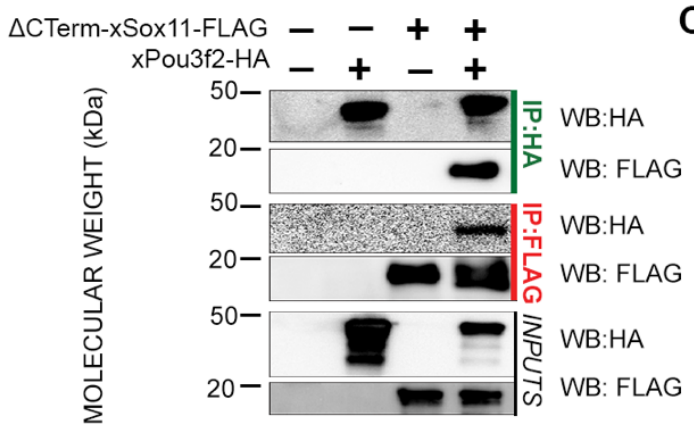

D

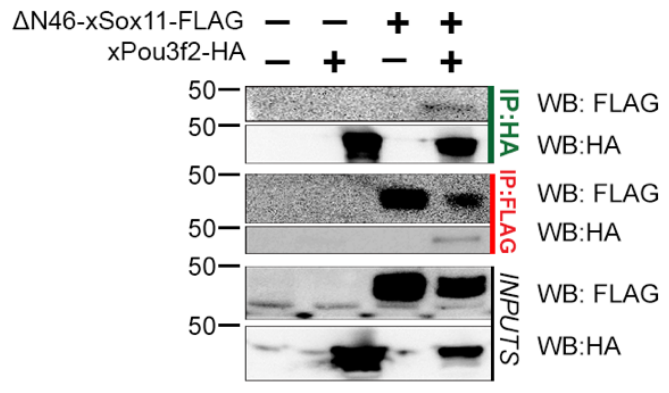

E $\triangle$ N46-xSox11-FLAG $-\quad-+$

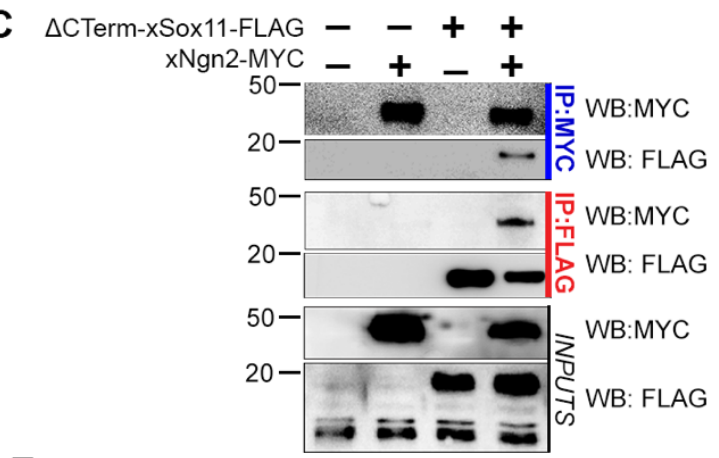

$\underset{50-}{\mathrm{NNgn} 2-\mathrm{MYC}} \boldsymbol{-}+\boldsymbol{+}+$

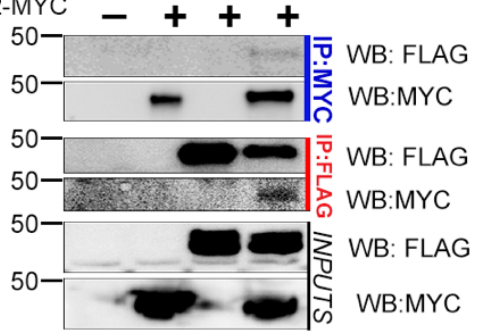

F $\quad \triangle \mathrm{HMG}-\mathrm{XSOX} 11-\mathrm{FLAG}-\boldsymbol{+}+\boldsymbol{+}$

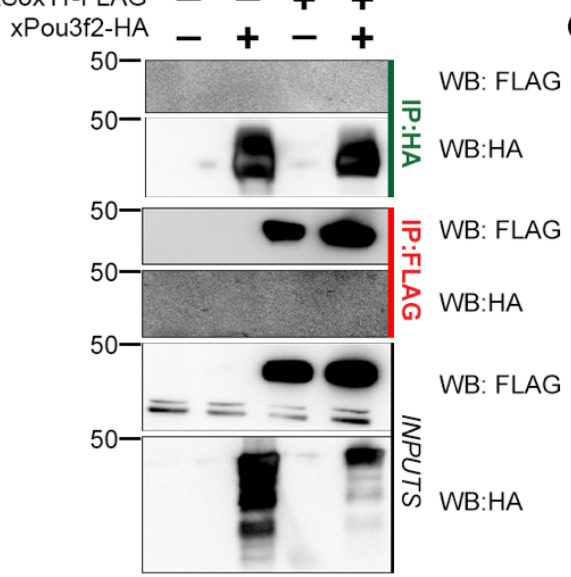

G $\triangle$ HMG-XSox11-FLAG $-\boldsymbol{+}+\boldsymbol{+}$

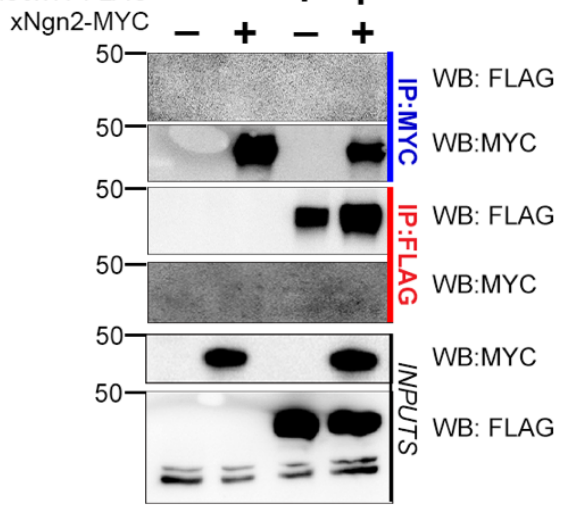

Figure 4 Sox11 N-terminus is essential for protein-protein interactions

A Schematic of xSox11domains including HMG domain (yellow), transactivation domain (orange) and FLAG tag (red) along with xSox11 deletion constructs. $\triangle$ N46-xSox11-FLAG that removes 46 amino acids upstream of the HMG domain, $\triangle$ HMG-xSox11-FLAG that removes the 72 amino acid HMG domain, and the $\Delta$ Cterm-xSox11-FLAG that removes 265 amino acids and contains only the N-terminus and HMG domain. C-G Immunoprecipitation (IP) of $\triangle$ Cterm-xSox11-FLAG, $\triangle$ N46-xSox11-FLAG or $\triangle H M G-$ xSox11-FLAG with xPou3f2-HA or xNgn2-MYC. Proteins were immunoprecipitated using either FLAG (red), HA (green), or MYC (blue) antibodies. Samples were analyzed by WB with anti-FLAG-HRP, antiHA-HRP, or anti-MYC-HRP. Inputs were ran as control. 

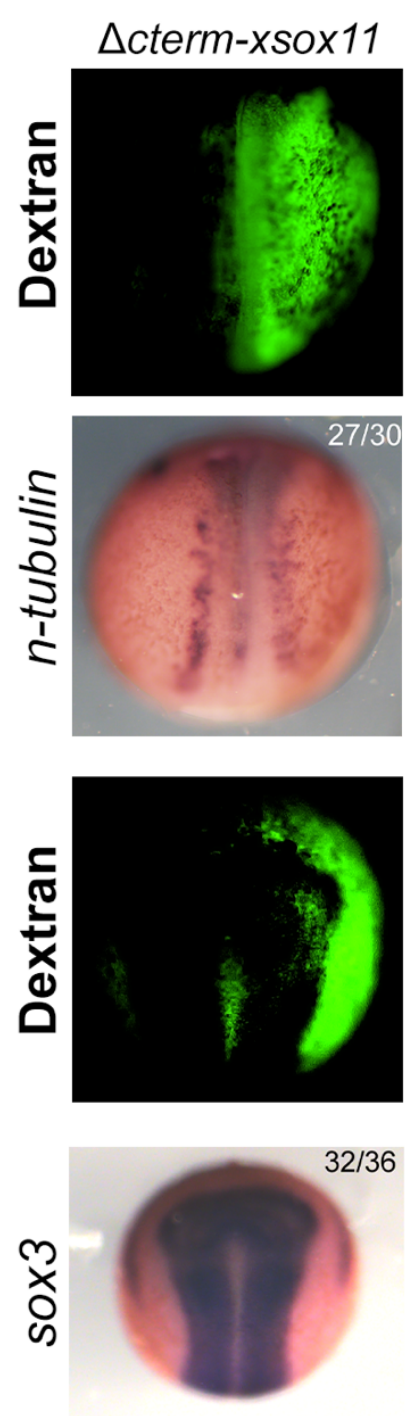
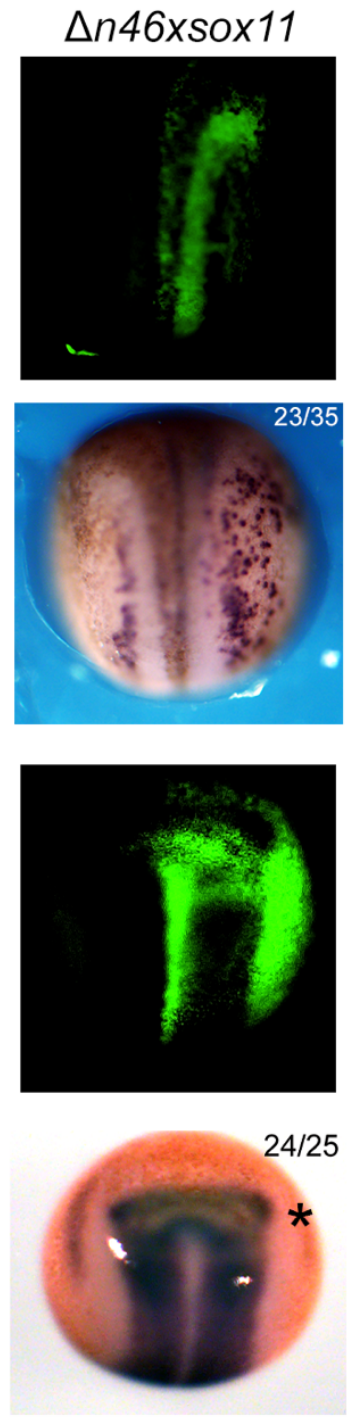

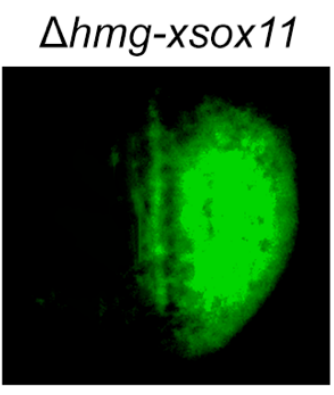

$22 / 22$
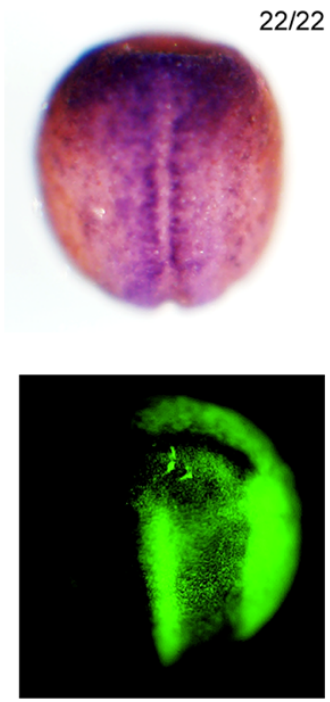

$19 / 20$

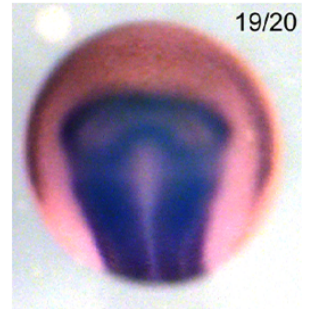

\section{$\Delta \operatorname{tad}-x \operatorname{sox} 11$}
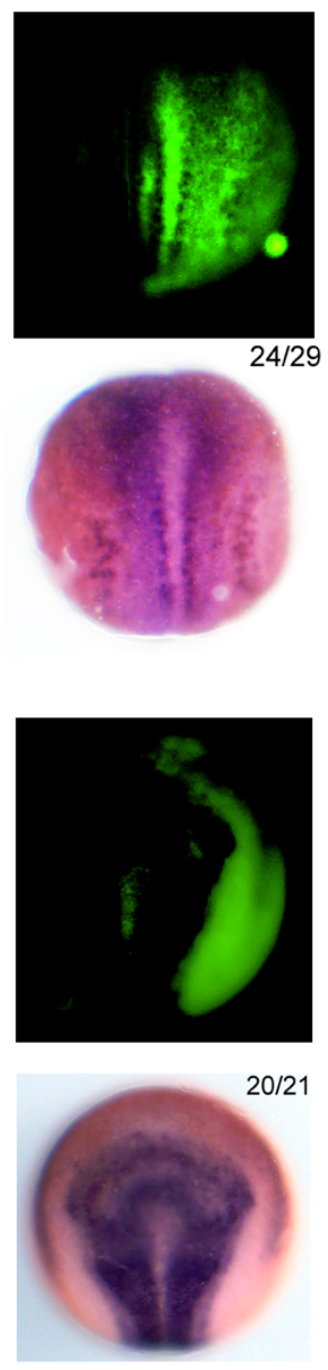

Figure 5 Sox11 C-terminus controls mature neuron formation.

WISH of neurula (stage 15) embryos injected in one of two cells (dorsal view, anterior to the top) with Dextran (green) and either $\Delta$ cterm-xsox11, $\Delta n 46$-xsox 11, $\Delta$ hmg-xsox 11, or $\Delta$ tad-xsox 11 mRNA. Embryos were then analyzed for expression of $n$-tubulin for mature neurons or sox 3 for neural progenitors. Asterisk shows reduction in placodal progenitors. Numbers in the upper right of each image denote the number of embryos with the phenotype over the total of embryos analyzed. 